\title{
Loss-controlled phytoplankton production in nutrient-poor littoral waters of the NW Mediterranean: in situ experimental evidence
}

\author{
Maria Paola Mura ${ }^{1, *}$, Susana Agustí ${ }^{1}$, Paul A. del Giorgio ${ }^{2}$, Josep M. Gasol ${ }^{3}$, \\ Dolors Vaqué ${ }^{3}$, Carlos M. Duarte ${ }^{1}$ \\ ${ }^{1}$ Centro de Estudios Avanzados de Blanes, CSIC, Cami de Santa Bárbara s/n, E-17300 Blanes, Girona, Spain \\ ${ }^{2}$ Département des Sciences Biologiques, Université du Québec à Montréal, Case Postal 8888, Succ. 'A', Montréal, \\ Province Québec, Canada H3C $3 \mathrm{P} 8$ \\ ${ }^{3}$ Institut de Ciències del Mar, CSIC, Passeig Comte de Borbó s/n, E-08039 Barcelona, Spain
}

\begin{abstract}
The role of losses in controlling phytoplankton biomass and production off Blanes Bay (NW Mediterranean) were examined, using in situ dialysis cultures, during a period of very low nutrient concentration. The ambient community expenenced a negative net growth rate $(-0.05 \pm 0.03$ divisions $\left.\mathrm{d}^{-1}\right)$, compared to relatively high community growth rates $\left(0.78 \pm 0.07\right.$ div. $\left.\mathrm{d}^{-1}\right)$ when metazoan grazers and physical losses, which appeared to bo negligible, were excluded, indicating that loss rates (0.83 div. $\mathrm{d}^{-1}$ ) exceeded growth rates. This provided evidence that the biomass and production of the phytoplankton community was controlled by consumers, even at a time of very low nutrient concentrations. The community structure changed in response to the suppression of losses, leading to an enhanced growth of nano- and microphytoplankton, while the abundance of picoplanktonic autotrophs tended to decline slightly. Yet, the bromass attained by nano- and microphytoplankton was similar despite large differences in thelr unitial density, indicating the existence of a resource limitation of the biomass the different groups may achieve. These results clearly provide evidence that the biomass and production of larger $(>5 \mu \mathrm{m})$ phytoplankton was controlled top-down by metazoan consumers, which were excluded from the dialysis bags, while picophytoplankton biomass was likely to be controlled by protists. This supports the notion that whether autotrophic production is channelled through metazoan herbivores or through the 'microbial loop' is closely dependent on the size (greater and smaller than about $5 \mu \mathrm{m}$, respectively) of the autotrophs, and that top-down control of phytoplankton production may occur even when nutrients are very scarce.
\end{abstract}

KEY WORDS: Phytoplankton - NW Mediterranean - Growth - Losses

\section{INTRODUCTION}

The NW Mediterranean is an oligotrophic environment, with generally low nutrient concentrations (Estrada \& Margalef 1988) that suggest nutrient limitation is a main constraint on primary production. This suggestion has been supported by evidence obtained for seagrasses (e.g. Pérez et al. 1991, 1994, Alcoverro et al. 1995) and macroalgae (Geertz-Hansen et al. 1994, Vidondo \& Duarte 1995), and by some evidence for

•E-mail: paola@ceab.es open sea phytoplankton (Krom et al. 1991, Estrada et al. 1993). These investigations all point to phosphorus as the main limiting nutrient in the NW Mediterranean, as supported by high carbon:phosphorus ratios in marine plants (Pérez et al. 1991, 1994, Delgado et al. 1994, Geertz-Hansen et al. 1994, Alcoverro et al. 1995, Vidondo \& Duarte 1995), and phosphate concentrations often below detection limits (e.g C. M. Duarte unpubl.).

There is, however, substantial evidence that points to the paramount importance of consumers in the NW Mediterranean plankton, such as very high biomass of microbial heterotrophs (D. Vaqué unpubl.) and zoo- 
plankton (P. Andreu \& C. M. Duarte unpubl.) relative to that of phytoplankton (M. P. Mura unpubl.). Also, there is a tendency for heterotrophs to dominate light absorption (Agustí 1994), and community planktonic metabolism (M. P. Satta, S. Agustí, M. P. Mura \& C. M. Duarte unpubl.) at annual time scales. That the biomass and metabolism of heterotrophs is very high relative to that of phytoplankton indicates that carbon demands should be high relative to production and, hence, a potential for top-down control of phytoplankton biomass and production.

The main seasonal phytoplankton bloom in the NW Mediterranean littoral occurs in late winter (late February to March; M. P. Mura unpubl.), when phytoplankton production greatly exceeds heterotrophic demands. The decline of this bloom is attributed to dissolved inorganic nutrient (particularly P) depletion (C. M. Duarte unpubl.), suggesting nutrient-limited production. However, it may derive equally from increased grazing pressure, for the bloom is followed by the recruitment of zooplankton (e.g. copepod nauplii and cnidaria; P. Andreu \& C. M. Duarte unpubl.) consumers. Field observations are, therefore, unable to elucidate whether the decline of the late winter phytoplankton bloom is due to grazing pressure or limited nutrient supply. These possibilities are, therefore, best examined through in situ experiments

Here we examine the role of losses in controlling phytoplankton production during a period of very low nutrient concentrations, following the late winter bloom. We do so based on the comparison, both for the total community and for different phytoplankton groups, of cell density, biomass, and net growth rates of the ambient phytoplankton with those measured in communities enclosed in dialysis bags in situ to exclude losses.

\section{METHODS}

The experiment was conducted in the Bay of Blanes,

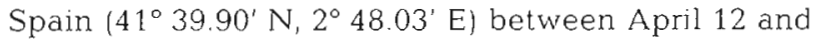
18,1994 , about $30 \mathrm{~d}$ after the late winter phytoplankton bloom, the single most important seasonal bloom in the area. The Bay of Blanes is a shallow $(<10 \mathrm{~m})$, exposed coastal zone with vertically mixed waters and little freshwater input during most of the year (C. M. Duarte unpubl.). Dissolved inorganic nutrient concen.trations are low, albeit well above detection limits, during most of the year, and fal.j to levels close to, or below, detection limits following algal blooms (C. M. Duarte unpubl.). The most important bloom (reaching about $3 \mathrm{mg}$ chlorophyll a (chl a) $\mathrm{m}^{-3}$ ) is observed in late winter (late February to March), phytoplankton biomass remaining at about 0.2 to $0.5 \mathrm{mg} \mathrm{chl} \mathrm{a} \mathrm{m}^{-3}$ during most of the year (M. P. Mura unpubl.). Planktonic respiration rates are similar to, or greater than, primary production rates during most of the year, except during the onset of phytoplankton blooms, when the planktonic community is net autotrophic (M. P. Satta, S. Agustí, M. P. Mura \& C. M. Duarte unpubl.).

Data on in situ conditions along the experimental period were derived from a sampling programme examining variation in e.g. water properties (temperature, salinity, dissolved inorganic nutrient concentrations), phytoplankton biomass and production, and community respiration (C. M. Duarte, M. P. Mura \& M. P. Satta unpubl.), and zooplankton biomass (P. Andreu \& C. M. Duarte unpubl.), at weekly intervals.

The experiment consisted of the examination of apparent growth rates of phytoplankton enclosed within dialysis bags, and suspended in situ at about $1.5 \mathrm{~m}$ below the surface. The dialysis cultures contained the unfiltered subsurface community that was screened through a $150 \mu \mathrm{m}$ mesh, and the natural community, screened through a $40 \mu \mathrm{m}$ mesh. Changes in phytoplankton abundance in ambient subsurface waters along the experiments were used as controls representing the net growth rate in situ (Tóth 1980 , Furnas 1982, 1990, Ferrier \& Rassoulzadegan 1991). Six dialysis bags were prepared for each of the treatments and consisted of $500 \mathrm{ml}$ bags constructed with dialysis membranes with a molecular weight cutoff (MWCO) of 6000 to 8000 . These membranes allow diffusion of molecules smaller than proteins, which equilibrate with ambient sea water at time scales $<4 \mathrm{~h}$. Dialysis bags were hydrated by soaking them in deionised water for $2 \mathrm{~h}$ prior to use. The bags were filled with subsurface water, unscreened or filtered, depending on the treatment, on deck of an outboard motor boat and closed. They were then carefully tied to a frame and suspended in the bay at $1.5 \mathrm{~m}$ depth. The shallow depth of the Bay of Blanes prevents light limitation, with subsurface light intensity varying between 500 and $1300 \mu$ Einstein $\mathrm{m}^{-2} \mathrm{~s}^{-1}$, compared to the $200 \mu$ Einstein $\mathrm{m}^{-2} \mathrm{~s}^{-1}$ necessary to saturate photosynthesis of this phytoplankton community (M. P. Satta unpubl. results) Hence, differences in light availability to phytoplankton cells suspended in the dialysis bags and in the natural community should have had no influence on the results obtained.

Three dialysis bags per treatment were sampled $3 \mathrm{~d}$ after and $6 \mathrm{~d}$ after initiation of the experiment. The contents were collected into a $500 \mathrm{ml}$ clean plastic container, and immediately transported to the laboratory. At the laboratory, a variable water volume (50 to 500 $\mathrm{ml}$, depending on phytoplankton biomass) was filtered through Whatman GF/F filters for fluorometric analysis of chl a concentration (Parsons et al. 1984). The filters were homogenised in $90 \%$ acetone and refrigerated 
for ca $6 \mathrm{~h}$. Fluorescence was measured, following extraction, in a Turner Designs fluorometer calibrated with pure chl a (Sigma Co., St. Louis, Missouri, USA) (Holm-Hansen \& Riemann 1978). An additional sample (100 to $250 \mathrm{ml}$ ) was preserved with glutaraldehyde (sample final concentration of $1.5 \%$ ) for microscopic examination of phytoplankton. A subsample of these samples (about $70 \mathrm{ml}$ ) was filtered at low pressure onto black Nuclepore filters $(0.8 \mu \mathrm{m}$ nominal pore size), and then stained with $1 \mathrm{ml}$ of DAPI $(4$, , 6-diamino-2phenylindole, a DNA-specific stain; Martinussen \& Thingstad 1991) solution $\left(10 \mu \mathrm{g} \mathrm{m}^{-1}\right)$ for 5 to $10 \mathrm{~min}$ without vacuum. Filters were then washed twice with filtered sea water before they were mounted on a glass slide over a drop of Zeiss immersion oil, and stored frozen until microscopical examination in the laboratory.

Epifluorescence microscopy, which allows unambiguous discrimination of autotrophic (i.e. containing chl a) from heterotrophic cells, was used to identify, enumerate, and measure phytoplankton cells. The phytoplankton cells collected on the filters were examined using a Zeiss Axioplan microscope equipped with an epifluorescence unit provided with an UV filter set (Zeiss filter 487701). The filters were examined at 400 and 1000 magnifications to count cells larger (40 to 50 fields) and smaller ( 30 fields) than $5 \mu \mathrm{m}$, respectively. Cells with diameters smaller than $5 \mu \mathrm{m}$ are referred to hereafter as picophytoplankton, and divided into prokaryotic and eukaryotic cells depending on whether chlorophyll autofluorescence was distributed over the cell or packed into chloroplasts, respectively; whereas phytoplanktonic cells with diameters between 5 and $20 \mu \mathrm{m}$ were considered as nanophytoplankton and cells with diameter $>20 \mu \mathrm{m}$ were classified as microplankton (Sieburth et al. 1978). Nano- and microphytoplankton were classified into genera. The average cell volume for each phytoplankton group identified in each sample was computed, by approximation to the nearest simple geometric shape, from the dimensions (at $1000 \times$ ) of ca 20 measured cells. The biovolume $\left(\mu \mathrm{m}^{3} \mathrm{ml}^{-1}\right)$ of the different phytoplankton groups in each sample was calculated as the product of cell density (cells $\mathrm{ml}^{-1}$ ) and average cell volume $\left(\mu \mathrm{m}^{3}\right.$ $\mathrm{cell}^{-1}$ ). This was then converted into carbon using published regression equations (Montagnes et al. 1994).

Growth rates ( $\mu$, doublings $\mathrm{d}^{-1}$ ) were calculated from changes in cell density $(D)$ with time $(t$, days) using the equation,

$$
\mu=\frac{\log _{2}\left(\frac{D_{t}}{D_{0}}\right)}{t}
$$

The rates calculated from the changes in phytoplankton concentrations in ambient waters and inside the dialysis bags were used to represent the net $\left(\mu_{\text {net }}\right)$ and gross $\left(\mu_{\text {gross }}\right)$ growth rates of phytoplankton, respectively (Tóth 1980, Furnas 1982, 1990). Accordingly, loss rates $\left(\mu_{\text {loss }}\right)$ were calculated as the difference between gross and net growth rates. Phytoplankton production was calculated as the rate of increase in phytoplankton carbon with time.

\section{RESULTS AND DISCUSSION}

The experiment followed the late winter bloom by about $1 \mathrm{mo}$, when chl a concentrations had dropped from the bloom levels of $3 \mathrm{mg} \mathrm{chl} \mathrm{a} \mathrm{m} \mathrm{m}^{-3}$ to about $0.3 \mathrm{mg}$ chl a $\mathrm{m}^{-3}$ (Fig. 1), the long-term modal value observed in the Bay of Blanes (C. M. Duarte unpubl. data). The late winter bloom was followed by a relatively strong wind event that upwelled water with higher nitrate concentrations into the shallow littoral (C. M. Duarte unpubl.). This mixing of water masses was clearly reflected in the $\mathrm{T}-\mathrm{S}$ (temperature-salinity) diagram (not shown), which also showed that the resulting water mass remained stable throughout the experiment.
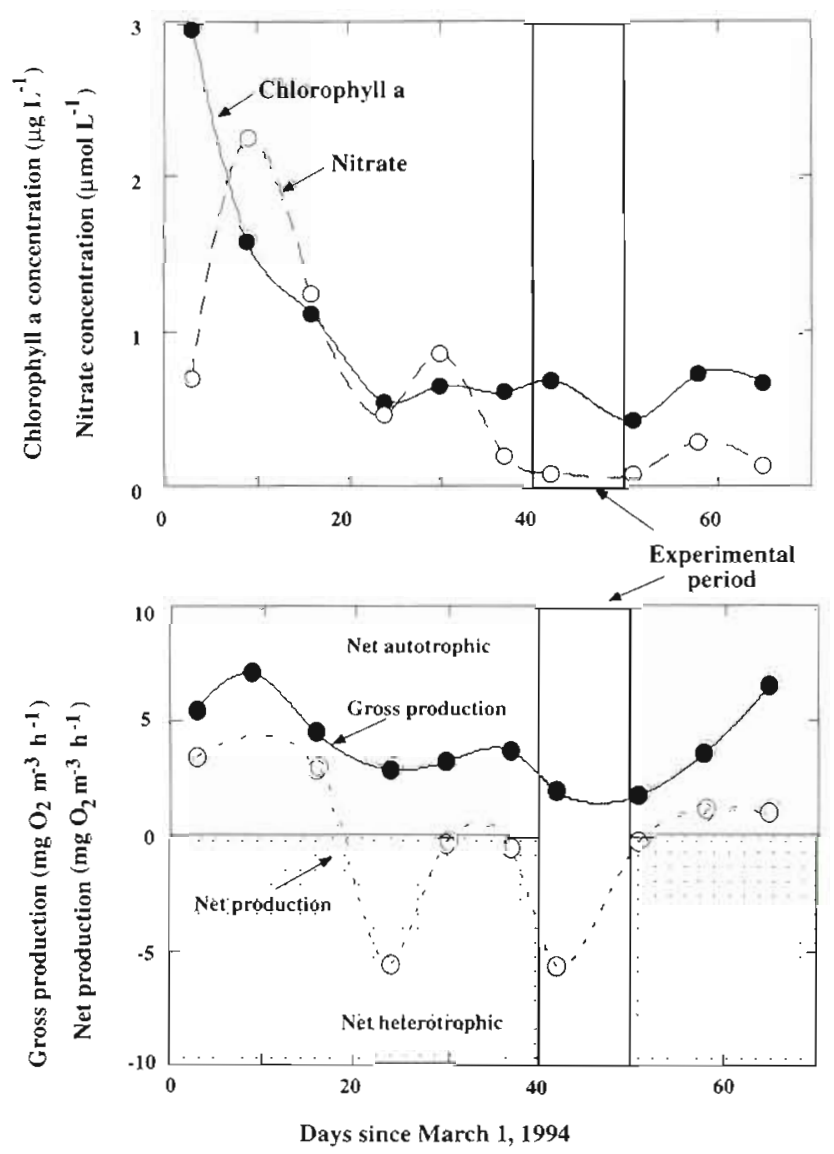

Fig. 1. Time course of nitrate concentration, chlorophyll a concentration, and gross and net production in the Bay of Blanes in spring 1994 
Nitrate concentrations declined from high $(>2 \mu \mathrm{M})$ values to reach very low concentrations (about $0.2 \mu \mathrm{M}$ ) during the experiment (Fig 1). Phosphate was only observed in measurable, albeit very low, concentrations $10 \mathrm{~d}$ before and $10 \mathrm{~d}$ after the experiment and remained below the analytical detection limit during the experiment. The waters were thoroughly mixed at this shallow $(6 \mathrm{~m})$ station, with daily average maximum wave heights ranging between 0.6 and $2 \mathrm{~m}$ during the experiment. The changes in nitrate concentrations were paralleled $(r=0.85, p<0.001)$ by similar fluctuations in gross production, suggesting that production may have been influenced by nitrate availability (Fig. 1). Examination of the temperature dependence of phytoplankton productivity in the Bay of Blanes showed the productivity during this period to also be constrained by the low water temperature $\left(14\right.$ to $\left.15^{\circ} \mathrm{C}\right)$ during the experimental period (M. P. Satta unpubl.). The phytoplankton bloom period was characterised by a dominance of photosynthesis over community respiration, which was reversed to a net heterotrophic community balance at the time of the experiment (Fig. 1). That community respiration exceeded production during the experimental period suggests high consumer demands, which could have probably exerted a controlling effect on phytoplankton production at that
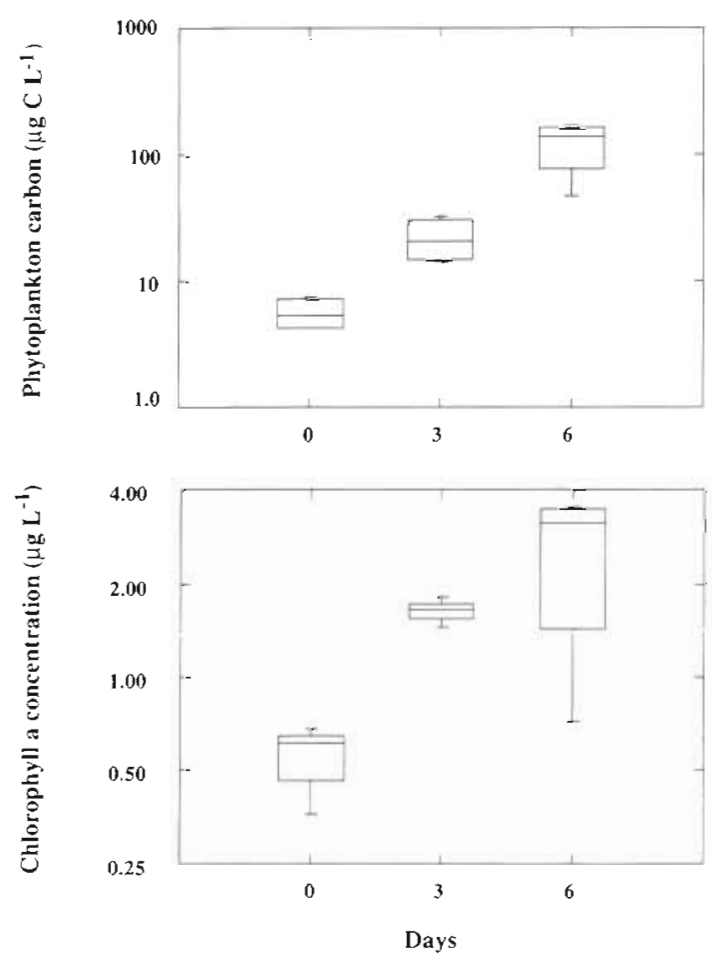

Fig. 2. Box plots showing the time course of phytoplankton biomass and chlorophyll a concentrations inside dialysis bags. The boxes encompass $50 \%$ of the data, the central line represents the median, and the bars encompass $95 \%$ of the data time. The zooplankton community present was relatively sparse, as is typical of spring conditions ( $P$. Andreu \& C. M. Duarte unpubl.), dominated by crustaceans (3900 to 7700 and 145 to 336 nauplii and copepods $\mathrm{m}^{-3}$, respectively) and gelatinous organisms (e.g. 52 to 65 siphonophores $\mathrm{m}^{-3}$ ). The low abundance of these organisms implied that they were mostly absent from the dialysis bags (i.e. $<1$ individual $500 \mathrm{ml}^{-1}$ ), except for nauplii (linear dimension about $170 \mu \mathrm{m}$ ), which may have been present, albeit with only a few individuals, in the unfiltered dialysis bags. Heterotrophic nanoflagellates and ciliates were present (about 600 and 2 cells $\mathrm{ml}^{-1}$, respectively), with abundances similar to average annual values (D. Vaqué unpubl.).

Phytoplankton biomass increased greatly in the dialysis bags, exceeding ambient biomass by about 100 fold after $6 \mathrm{~d}$, and achieving similar biomasses in all 3 dialysis treatments (see Fig. 5). Hence, phytoplankton production inside the bags increased substantially to reach production rates $\left(41.9 \pm 8.5 \mu \mathrm{g} \mathrm{Cl}^{-1} \mathrm{~d}^{-1}\right)$ exceeding ambient production (about $13 \mu \mathrm{g} \mathrm{Cl}^{-1} \mathrm{~d}^{-1}$, inferred from oxygen evolution rates in Fig. 1 using conversion factors as in Parsons et al. 1984) by about 3- to 4 -fold. The final biomass reached $\left(150 \pm 19 \mu \mathrm{g} \mathrm{C} \mathrm{l}^{-1}\right.$; Fig. 2) corresponded to a chl a concentration of $3.26 \pm 0.3 \mu \mathrm{g}$ chl a $\mathrm{l}^{-1}$ (Fig. 2), which is the modal biomass achieved by phytoplankton blooms in the Bay of Blanes (Mura et al. 1995). This indicates that phytoplankton communities are able to reach biomasses and production rates characteristic of bloom conditions at the very low nutrient concentrations observed during the experimental period. Accordingly, the low phytoplankton biomass and production observed in Blanes Bay at the time of the experiment was a result of substantial losses, rather than of resource limitation. This was further supported by examination of growth rates, which showed a net loss rate for phytoplankton in ambient waters $\left(\mu_{\text {net }}=\right.$ $-0.05 \pm 0.03$ divisions $\mathrm{d}^{-1}$ ), whereas their gross growth rate - as observed inside the dialysis bags - was quite high $\left(\mu_{\text {gross }}=0.78 \pm 0.07 \mathrm{div}\right.$. $\left.\mathrm{d}^{-1}\right)$. Losses due to advection and diffusion must have been low, since waters remained well mixed during the study and no evidence of mixing of water masses was observed during the experiment. Hence, the substantial losses indicated by the results must be largely attributable to grazing by metazoans, which were excluded from the dialysis bags. These losses appeared to be very high in the Bay of Blanes, at about 0.83 div. $\mathrm{d}^{-1}$, suggesting a strong top-down control of phytoplankton biomass and production there, even at a time of very low nutrient concentrations.

A detailed examination of the community response showed major changes in community structure and growth in response to the experimental enclosure inside dialysis bags. The natural community (i.e. that 
present at $t=0$ ) was dominated both in numbers and biomass by picoplankton, both prokaryotic (about $43 \%$ of the biomass) and eukaryotic (about $22.3 \%$ of the biomass), with diatoms (dominated by those in the genus Chaetoceros) also having a significant (about $33.6 \%$ of the biomass) contribution to community biomass (Fig. 3). The enclosed communities changed greatly in response to the suppression of losses, with a rapid initial response of diatoms (Chaetoceros and Nitzschia species) followed by a response of photosynthetic nanoflagellates by the end of the experiment (Fig. 3). In contrast with the enhanced growth experienced by nano- and microphytoplankton, the concentration of picoplanktonic autotrophs tended to decline slightly (Fig. 3). Dinoflagellates were present below detection limits at the initiation of the experiment, but developed a detectable biomass inside the dialysis bags as well as in the natural (i.e. the open water) community. The lack of initial density estimates, however, precluded the estimation of net growth rates for dinoflagellates (Fig. 4).

The growth rate of nano- and microphytoplanktonic groups increased greatly inside the bags, allowing calculation of gross growth rates. Gross growth rates were quite high, at about one or more divisions per day for photosynthetic nano- and microplankton (Fig. 4), clearly demonstrating the rather low nutrient concentrations in the Blanes Bay waters to be sufficient to support fast growth of these taxa. In contrast, the growth
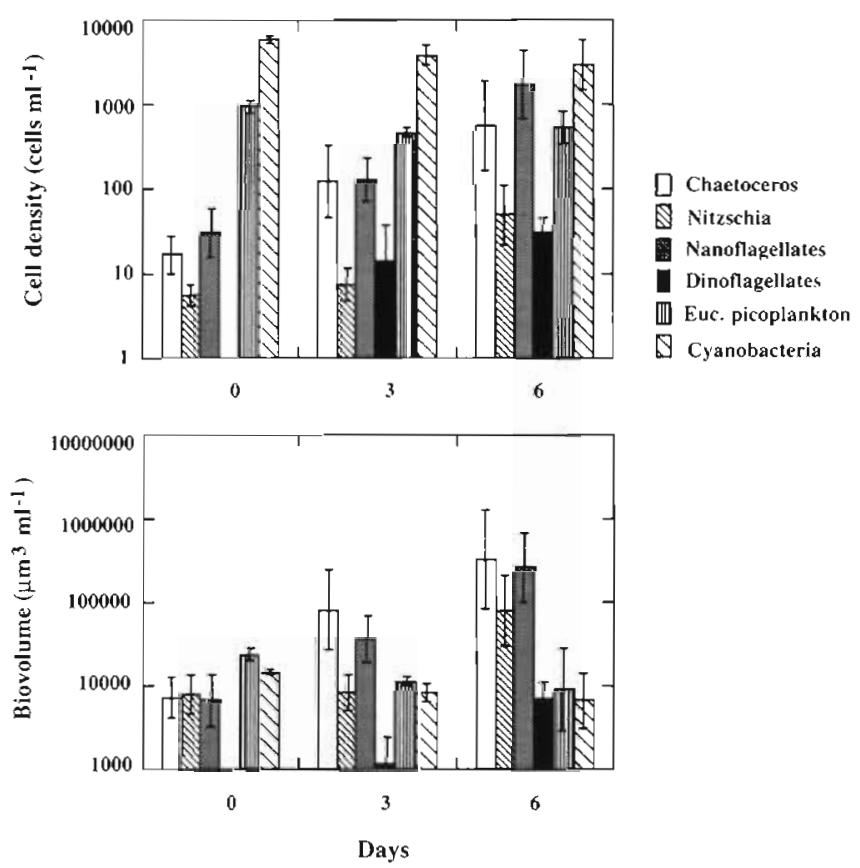

Fig. 3. Time course of the biomass and density of the main phytoplankton groups present in the community inside the dialysis bags. Error bars show $\pm 1 \mathrm{SE}$

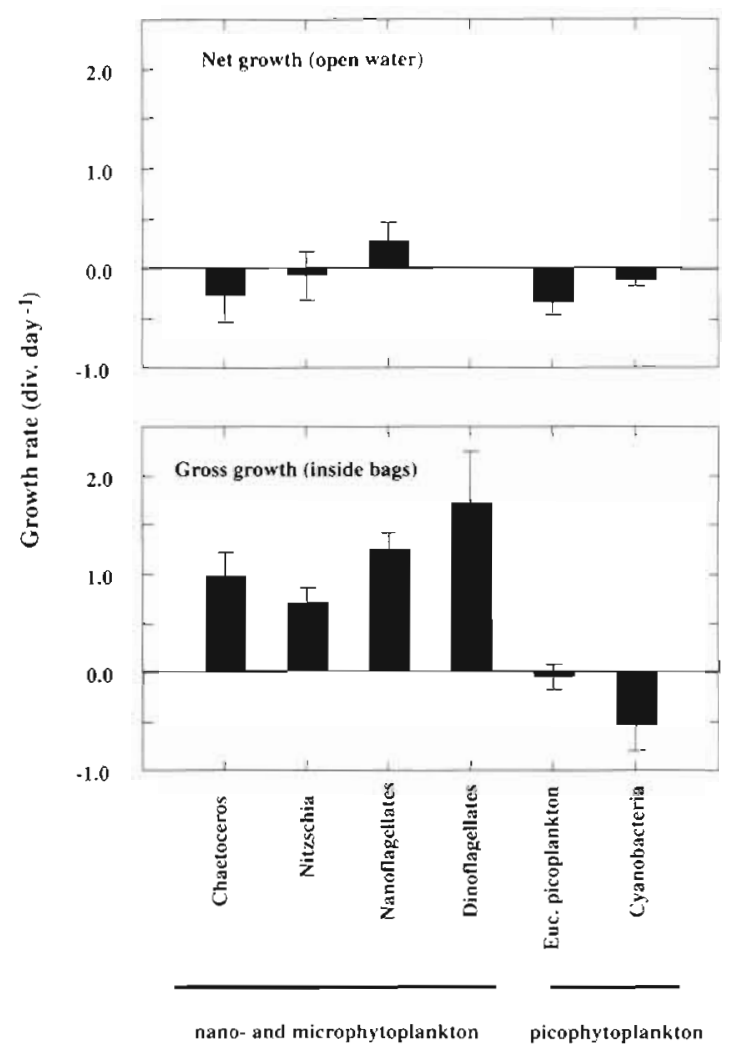

Fig. 4. Mean ( \pm SE) apparent phytoplankton growth rates in the open water community (i.e. net growth rates), and inside dialysis bags (i.e. gross growth rates for nano- and microphytoplankton)

rate of picoplanktonic autotrophs did not increase, but declined, after enclosure in dialysis bags (Fig. 4). This indicates that the main source of losses of picophytoplankton operated inside the bags, and points to heterotrophic protists, which were present inside the dialysis bags (D. Vaqué unpubl. data), as the organisms responsible for these losses. Loss rates for nano- and microphytoplankton, calculated as the difference between gross and net growth rate, were high, particularly for Chaetoceros species (about $1.27 \log _{2}$ units $\mathrm{d}^{-1}$ ), for which losses exceeded gross growth rates, resulting in a negative net growth rate in the open water community (Fig. 4).

Examination of the growth response of phytoplankton under the different treatments revealed a remarkable convergence in the final biomass reached by different nano- and microphytoplankton taxa within the dialysis bags despite order-of-magnitude differences in their initial density among treatments (Fig. 5). The screening treatment $(<150$ and $<40 \mu \mathrm{m}$ ) induced sizeable changes in the initial density of the groups, diluting some of the taxa (e.g. Chaetoceros species) relative to the ambient waters. That final abundances were remarkably close despite substantial changes in initial 

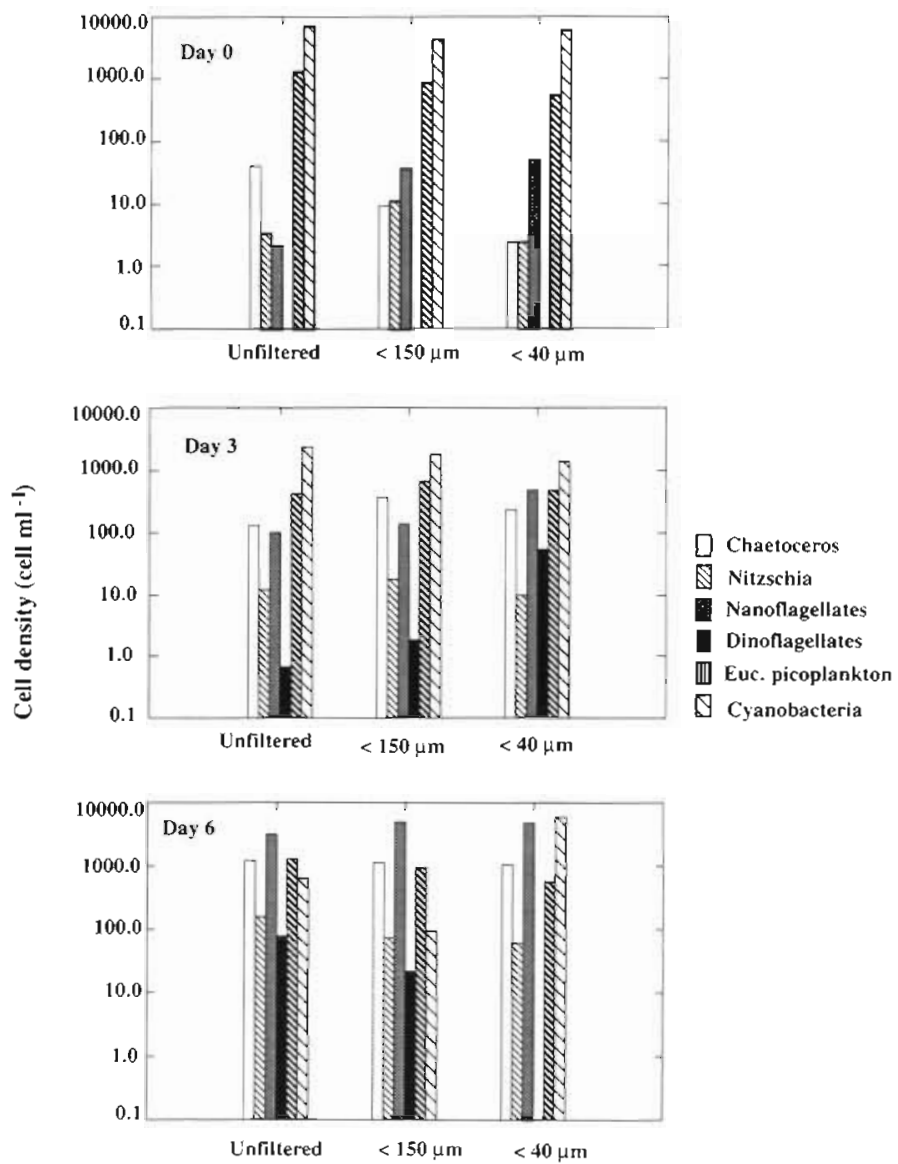

Fig. 5. Time course of the density of the main taxa present in the phytoplankton community inside dialysis bags containing unfiltered water, and water filtered through 150 and $40 \mu \mathrm{m}$ nets

density implies that diluted populations must have supported faster apparent growth rates than denser ones. Alternatively, all populations may have supported similar growth rates until the asymptotic biomass was achieved with initially sparse populations thereby maintaining maximal growth rates over longer time periods. Hence, the apparent growth rates of phytoplankton taxa (e.g. Chaetoceros species and eucaryotic picoplankton) calculated over the experimental period declined with increasing initial density (Fig. 6). These results provide strong evidence for the existence of an asymptotic biomass, which must be imposed by resource (e.g nutrients) limitation of biomass yield.

In summary, the results obtained show a major shift in the abundance, production, and growth rate of nano- and microphytoplankton in response to enclosure inside dialysis bags, whereas those of picoplankton showed only a minor response. These results suggest the biomass and production of larger (>5 $\mu \mathrm{m}$ )
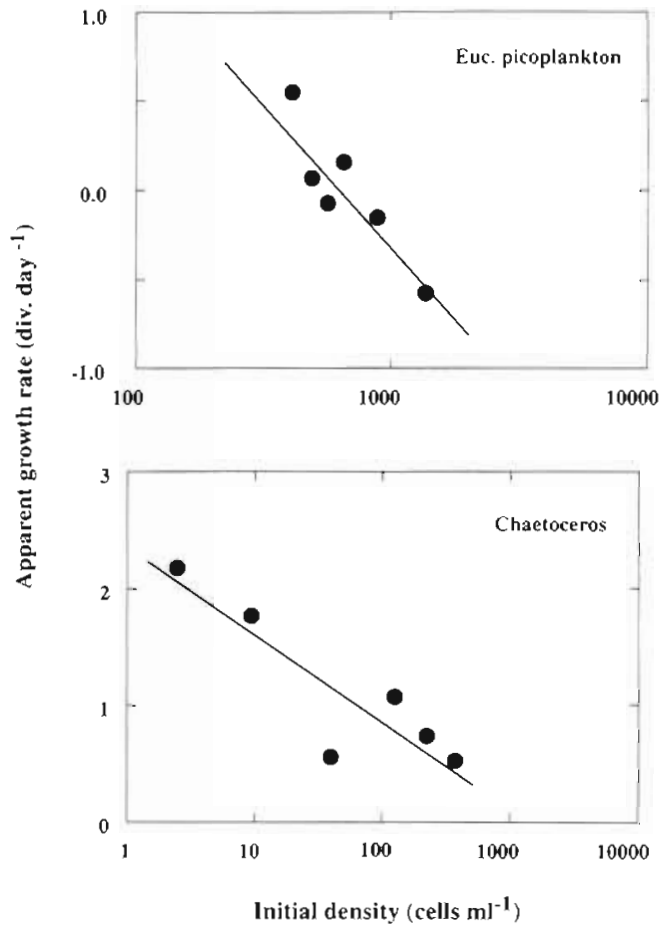

Fig. 6. Relationship between the apparent growth rate of Chaetoceros species and eukaryotic picoplankton and their initial density in dialysis bags. Solid line represents the fitted regression equations

phytoplankton in Blanes Bay is controlled by metazoan consumers, and show the potential for phytoplankton to reach bloom levels even during periods of very low nutrient concentrations. The experiment also provided evidence that picophytoplankton biomass is controlled by protists, rather than metazoans (cf. Rassoulzadegan \& Sheldon 1986). Hence, our results are consistent with the notion that whether autotrophic production is channelled through metazoan herbivores or through the 'microbial loop' is closely dependent on the size (greater and smaller than about $5 \mu \mathrm{m}$, respectively) of the autotrophs (Landry \& Hassett 1982, Cushing 1989, Kuuppo-Leinikki 1990, Legendre 1990, Rassoulzadegan 1993, Legendre \& Rassoulzadegan 1995). Phytoplankton communities are, therefore, able to support substantial growth rates even during these oligotrophic conditions. However, the evidence for a constant yield, and the associated density dependence, obtained (Fig. 6) indicates that apparent growth rates are maintained below maximal levels by resource (i.e. nutrient) limitation. In conclusion, the biomass and production of the phytoplankton community appeared limited during the low-nutrient period investigated by metazoan grazers, although their growth rate was maintained below maximal values by the limited nutrient supply. 
Acknowledgements. This is a contribution to project MAR-940746 funded by the Spanish Interministerial Commission for Science and Technology (CICYT). M.P.M., P.A.d.G., and J.M.G. were supported by grants from the CE, FCAR, and CSIC, respectively. We thank G. Carreras, T Cámara, and R. H. Peters for assistance in the field, and P. Andreu for examining the zooplankton samples.

\section{LITERATURE CITED}

Agustí S (1994) Planktonic size structure and the photon budget of the euphotic ocean. In: Rodriguez J, Li WKW (eds) The size structure and metabolism of the pelagic ecosystem. Scient Mar 58:109-117

Alcoverro T, Duarte CM, Romero J (1995) Annual growth dynamics of Poseidonia oceanica: contribution of largescale versus local factors to seasonality. Mar Ecol Prog Ser 120:203-210

Cushing DH (1989) A difference in structure between ecosystems in strongly stratified waters and in those that are only weakly stratified. J Plankton Res 11:1-13

Delgado O, Ballesteros E, Vidal M (1994) Seasonal variation in tissue nitrogen and phosphor us of Cistosteira mediterranea Sauvagean (Fucales, Phaeophyceae) in the Northwestern Mediterranean Sea. Bot Mar 37:1-9

Estrada M, Margalef R (1988) Supply of nutrients to the Mediterranean photic zone across a persistent front. Oceanol Acta Spec Issue 9:133-142

Estrada M, Marrasé C, Latasa M, Berdalet E, Delgado M, Riera I (1993) Variability of deep chlorophyll a maximum characteristics in the Northwestern Mediterranean. Mar Ecol Prog Ser 92:289-300

Ferrier C, Rassoulzadegan F (1991) Density-dependent effects of protozoans on specific growth rates in pico- and nanoplanktonic assemblages. Limonol Oceanogr 36(4): $657-669$

Furnas MJ (1982) Growth rate of summer nanoplankton $(<10 \mu \mathrm{m})$ populations in lower Narragansett Bay, Rhode Island, USA. Mar Biol 70:105-115

Furnas MJ (1990) In situ growth rates of marine phytoplankton: approaches to measurement, community and species growth rates. J Plankton Res 12(6):1117-1151

Geertz-Hansen O, Enríquez S, Duarte CM, Agustí A, Vaqué D. Vidondo B (1994) Functional implications of the form of Codium bursa, a balloon-like Mediterranean macroalga. Mar Ecol Prog Ser 108:153-160

Holm-Hansen O, Riemann B (1978) Chlorophyll a determination improvements in methodology. Oikos 30:438-447

This article was submitted to the editor
Krom MD, Kress N, Brenner S, Gordon LI (1991) Phosphorus limitation of primary productivity in the eastern Mediterranean Sea. Limnol Oceanogr 36:424-432

Kuuppo-Leinikki P (1990) Protozoan grazing on planktonic bacteria and its impact on bacterial population. Mar Ecol Prog Ser 63:227-238

Landry MR, Hassett RP (1982) Estimating the grazing impact of marine microzooplankton. Mar Biol 67:283-288

Legendre L (1990) The significance of microalgal blooms for fisheries and for the export of particulate organic carbon in oceans. J Plankton Res 12:681-699

Legendre L, Rassoulzadegan F (1995) Plankton and nutrient dynamics in marine waters. Ophelia 41:153-172

Martinussen I, Thingstad TF (1991) A simple double staining technique for simultaneous quantification of auto- and heterotrophic nano- and picoplankton. Mar microb Food Webs 5:5-11

Montagnes DJS, Berges JA, Harrison PJ, Taylor FJR (1994) Estimating carbon, nitrogen, protein, and chlorophyll a from volume in marine phytoplankton. Limnol Oceanogr 39:1044-1060

Parsons TR, Maita Y, Lalli CM (1984) A manual of chemical and biological methods for seawater analysis. Pergamon Press, Oxford

Pérez M, Duarte CM, Romero J, Sand-Jensen K, Alcoverro T (1994) Growth plasticity in Cymodocea nodosa stand: the importance of nutrient supply. Aquat Bot 47:249-264

Pérez M, Romero J, Duarte CM, Sand-Jensen K (1991) Phosphorus limitation of Cymodocea nodosa growth. Mar Biol 109:129-133

Rassoulzadegan F (1993) Protozoan patterns in the AzamAmmenman's bacteria-phytoplankton mutualisms. In: Guerrero R, Pedrós-Alió C (eds) Trends in microbial ecology. Spanish Society for Microbiology, p 4435-4439

Rassoulzadegan F, Sheldon RW (1986) Predator-prey interactions of nanozooplankton and bacteria in an oligotrophic marine environment. Limnol Oceanogr 31(5): 1010-1021

Sieburth JMcN, Smetacek V, Lenz J (1978) Pelagic ecosystem structure: heterotrophic compartments of the plankton and their relation to plankton size fractions. Limnol Oceanogr 23:1256-1263

Tóth LG (1980) The use of dialysing sacks in estimation of production of bacterioplankton and phytoplankton. Area Hydrobiol 89:474-482

Vidondo B, Duarte CM (1995) Seasonal growth of Codium bursa, a slow growing Mediterranean macroalga: in situ experimental evidence of nutrient limitation. Mar Ecol Prog Ser 123:185-191

Manuscript first received: December 5, 1994

Revised version accepted: July 13, 1995 